\section{The Microbes Within}

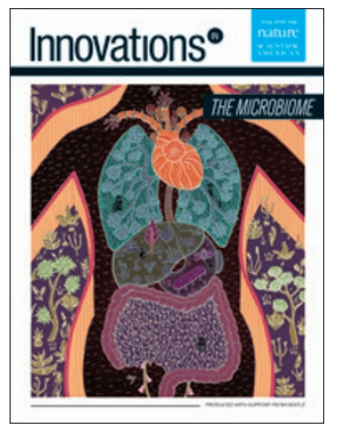

ANTONY VAN LEEUWENHOEK WROTE TO the Royal Society of London in a letter dated September 17, 1683, describing "very little animalcules, very prettily a-moving," which he had seen under a microscope in plaque scraped from his teeth. For more than three centuries after van Leeuwenhoek's observation, the human "microbiome" - the 100 trillion or so microbes that live in various nooks and crannies of the human body - remained largely unstudied, mainly because it is not so easy to extract and culture them in a laboratory. A decade ago the advent of sequencing technologies finally opened up this microbiological frontier. The Human Microbiome Project reference database, established in 2012, revealed in unprecedented detail the diverse microbial community that inhabits our bodies.

Most live in the gut. They are not freeloaders but rather perform many functions vital to health and survival: they digest food, produce antiinflammatory chemicals and compounds, and train the immune system to distinguish friend from foe. Revelations about the role of the human microbiome in our lives have begun to shake the foundations of medicine and nutrition. Leading scientists, including those whose work and opinions are featured in the pages that follow, now think of humans not as selfsufficient organisms but as complex ecosystems colonized by numerous collaborating and competing microbial species. From this perspective, human health is a form of ecology in which care for the body also involves tending its teeming population of resident animalcules.

This special report on Innovations in the Microbiome, which is being published in both Scientific American and Nature, is sponsored by Nestlé. It was produced independently by Scientific American editors, who have sole responsibility for all editorial content. Beyond the choice to sponsor this particular topic, Nestlé had no input into the content of this package.

David Grogan Section Editor s3 The Peacekeepers

Amid the trillions of microbes that live in the intestines, scientists have found a few species that seem to play a key role in keeping us healthy. By Moises Velasquez-Manoff

\section{s13 Thinking from the Gut}

The microbiome may yield a new class of psychobiotics for the treatment of anxiety, depression and other mood disorders.

By Charles Schmidt

\section{EXPERT COMMENTARIES:}

s5 Why Microbiome Treatments Could Pay Off Soon

Effective interventions may come before all the research is in. By Rob Knight

s7 The Gene-Microbe Link

Evidence that genes shape the microbiome may point to new treatments for common diseases.

By Ruth E. Ley

s10 Microbiome Engineering Synthetic biology may lead to the creation of smart microbes that can detect and treat disease. By Justin L. Sonnenburg

s14 The Diverse Microbiome of the Hunter-Gatherer

The Hadza of Tanzania offer a snapshot of the co-adaptive capacity of the gut ecosystem. By Stephanie L. Schnorr

INFOGRAPHIC:

s9 Your Microbes at Work: Fiber Fermenters Keep Us Healthy

\section{EDITORIAL}

EDITOR IN CHIEF AND SENIOR VP Mariette DiChristina EXECUTIVE EDITOR Fred Guterl MANAGING EDITOR Ricki L. Rusting SECTION EDITOR David Grogan

\section{DESIGN DIRECTOR} Michael Mrak CONSULTING ART DIRECTOR Kelly Buckheit Krause CONSULTING EDITOR Christine Gorman COPY DIRECTOR Maria-Christina Keller
COPYEDITORS

Michael Battaglia, Daniel C. Schlenoff, Aaron Shattuck MANAGING PRODUCTION EDITOR Richard Hunt SENIOR PRODUCTION EDITOR Michelle Wright
SENIOR PRODUCTION MANAGER Christina Hippeli PREPRESS AND QUALITY MANAGER Silvia De Santis VP GLOBAL MEDIA ALLIANCES Jeremy Abbate MARKETING MANAGERS Pauline Bernfeld, Diane Schube
PUBUSHER

Richard Hughes HEAD OF SPONSORSHIP Reya Silao

SPONSORSHIP PROJECT MANAGER Yvette Smith 